\title{
USP SERVIÇOS: UM CATÁLOGO PARA A EDUCAÇÃO
}

Em dezembro de 1995, a Universidade de São Paulo, através da Coordenadoria Executiva de Cooperação Universitária e Atividades Especiais - CECAE, lançou a versão impressa e a versão eletrônica do catálogo USP/Serviços-Educação. Em março estará também disponível, através de terminais de computadores em rede, na Internet.

Trata-se de uma publicação concebida no mesmo espírito que estimulou a edição, em 1989, de outro trabalho semelhante (o USP/Serviços), isto é, informar a todos os cidadãos sobre os serviços oferecidos pela Universidade e, ao mesmo tempo, colocálos à disposição da sociedade. Desta vez, foram destacadas, no conjunto das atividades universitárias, aquelas que mais de perto visam atender à comunidade educacional externa à Universidade. Ou seja, a todos os profissionais da rede de ensino de primeiro e segundo graus e a todos os estudantes, aos pais e mães que esperam receber serviços educacionais de boa qualidade.

Maior aproximação com todos os segmentos educacionais é a meta principal que

\section{A AUTORA}

Vera Soares

Coordenadora do Programa de Cooperação Universidade-Sistema Escolar da CECAE/USP. esperamos alcançar com a realização deste projeto, para que dela surja o desenvolvimento de uma relação mais íntima com a Universidade.

\section{MAIOR INTEGRAÇÃO}

O USP/Serviços-Educação pode tornar-se um rico instrumento para os professores e profissionais da educação, preocupados em encontrar novos caminhos para as atividades dentro e fora das salas de aula. Esse catálogo indica serviços, profissionais, projetos, atividades que podem ser acessados e que poderão auxiliar o cotidiano escolar. Para as escolas, inclusive de outros Estados, por exemplo, será uma forma de avaliar melhor as possibilidades que a Universidade oferece para superar distâncias geográficas e culturais.

Para as equipes das diversas unidades acadêmicas relacionadas na publicação, será motivo de satisfação receber as solicitações geradas pelo catálogo, contribuindo assim para o aprimoramento da Educação.

A publicação do USP/ServiçosEducação sinaliza a amplitude e a multiplicidade das possibilidades de integração entre a Universidade de São Paulo e o sistema educacional. 
Neste volume, o usuário encontrará um elenco de unidades acadêmicas, cursos e produtos didáticos e de divulgação cultural e científica. Poderá também escolher entre uma relação especializada de serviços de orientação, assessoria e consultoria. Estão identificados cerca de 400 serviços que são regularmente oferecidos em diversas áreas. Há inúmeras formas pelas quais a comunidade escolar de primeiro e segundo graus pode contar com a Universidade no desenvolvimento de suas atividades cotidianas ou para projetos de interesse comum.

Os serviços estão agrupados nas seguintes categorias: orientação para docentes e estudantes; assessoria e consultoria; cursos; divulgação cultural e científica; produção de material didático; museus; bi-

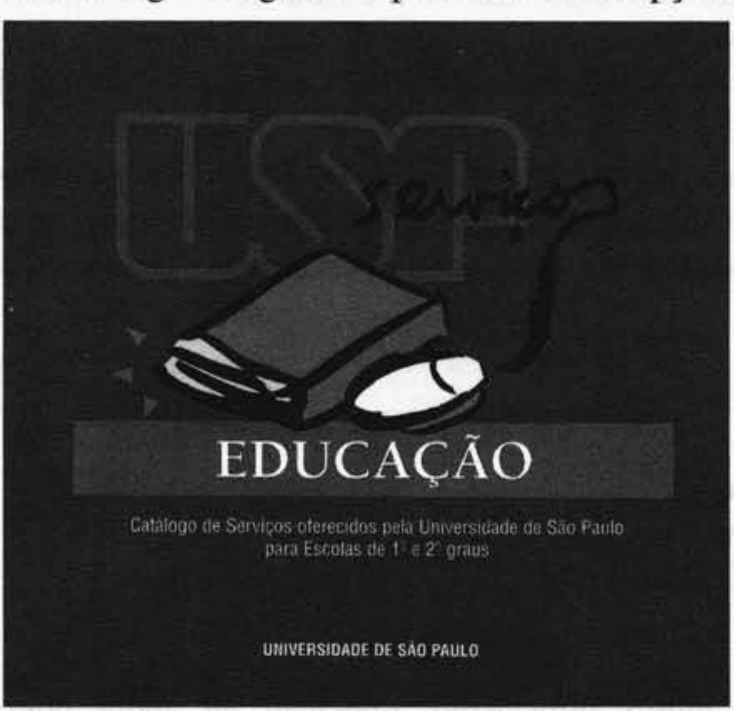

O Catálogo USP/Educação pode ajudar a comunidade a utilizar melhor os recursos da Universidade. através da Relação dos Endereços, obtêmse as formas de acesso.

Na versão eletrônica, existe maior agilidade na busca e localização dos serviços. A opção é navegar entre uma área de interesse e identificar os serviços oferecidos, ou buscar por palavras a descrição dos serviços, ou pela relação de Unidades da Universidade, ou ainda mesclando diversas palavras. Cada opção selecionada expõe na tela do microcomputador a definição do serviço, o departamento ou outro órgão responsável pela realização, a área e as diversas formas de contato. A exigência para instalação da versão eletrônica, além do microcomputador, é dispor do programa Windows.

O Programa de Cooperação Universidade-Sistema Escolar, da CECAE, bliotecas; empréstimos de filmes e material audiovisual; visitas monitoradas e outros. $\mathrm{Na}$ abertura de cada serviço, existe uma breve explicação sobre cada um deles.

$\mathrm{Na}$ versão em papel, é possível encontrar informações para se chegar a um centro especializado, ao atendimento desejado ou a um curso de interesse. Através do Sumário, busca-se uma categoria de serviços e pode-se identificá-lo tanto pelas áreas do conhecimento, como por assuntos ou autores. Na Relação de Endereços, encontram-se as formas de contato. Pelo Índice de Unidades e Serviços, identificam-se as unidades e as páginas em que se encontra a descrição do serviço e, depois, responsável pela elaboração e edição, encara este catálogo como potencial gerador de projetos de colaboração com as instituições escolares, de parcerias e conjugações de esforços de modo continuado e interativo com a rede de ensino.

Para saber como adquirir o Catálogo USP/Serviços-Educação contatar a Coordenadoria Executiva de Cooperação Universitária e de Atividades Especiais - CECAE - Av. Prof. Luciano Gualberto, 374 - Trav. J (antigo prédio da Reitoria), $7^{\circ}$ andar Cidade Universitária. 05508-900 - São Paulo - SP - Fone: (011) 8184490 - Fax (011) 2110922 -e-mail.: cecae@org.usp.br. 